\title{
Leadership Skills of Faculty Members at Al- Istiqlal University: Cadets' Point of Views
}

\author{
Mahmoud A Abu Samra ${ }^{1, *}$ \\ ${ }^{1}$ Faculty of Educational Sciences, AL-Quds University, Jerusalem, Palestine \\ *Correspondence: Faculty of Educational Sciences, AL-Quds University, P. O. Box 20002, Jerusalem, Palestine. Tel: \\ 970-598-912-000. E-mail: m_abusamra@yahoo.com
}

Received: April 26, 2014

doi:10.5430/wje.v4n3p36
Accepted: May 18, 2014

Online Published: May 23, 2014

URL: http://dx.doi.org/10.5430/wje.v4n3p36

\begin{abstract}
The aim of this study is to determine the availability of leadership skills of faculty members (civilian and military personnel) at Al- Istiqlal university (AIU). The population of the study was composed of AIU students, including juniors and sophomores. A random sample, consisting of 137 cadets, was chosen. The researcher developed a questionnaire to measure the leadership skills of faculty members. The study results showed that the leadership skills of faculty members at AIU are moderately available, where the average was 2.10 according to three -points Likert scale. They also revealed that the leadership skills of civilian faculty members were higher than those of the military personnel on all domains of the study. Moreover, they indicated that there were no statistically significant differences in the availability of leadership skills attributed to all variables of the study. Based on the results of the study, certain recommendations were presented which assist in achieving objectives of the study as well as the objectives of AIU, collectively.
\end{abstract}

Keywords: leadership skills; faculty members; Al- Istiqlal university

\section{Introduction}

For many years, people were astonished by the phenomena of leadership and they pondered the unique skills that make good leaders, the reasons that lead a group of people to reject their leader, the modality in which to choose the leader, and other related questions. In order to answer these questions and due to the fact that the leadership term indicates multiple connotations, several studies were conducted in the fields of sociology, psychology, pedagogy, and management to formulate certain results that aid in understanding questions concerned with leadership as a whole. These studies were confined to two aspects: The first aspect concerns leaders' characteristics, while the second focuses on leadership styles.

These studies agreed on the necessity of leadership and its importance to the institutions regardless of their disciplines and levels. Not only is this necessary in specific institutions, but it is an integral portion in the advancement potential of higher education institutions, particularly universities such as AIU who train and graduate officers that proceed to maintain and implement security measures in Palestine. Such a university has the responsibility to build and support security services in the Palestinian society by training and advancing leaders of high competencies and leadership skills. In addition, the faculty members are responsible for interacting with cadets and shaping their personalities. The aforementioned propositions each require unique attention, special resources, and a university professor leader who possesses leadership traits and skills, so that the university may guarantee the future of its graduate leaders. McGonigle et al. (2002) asserted that retaining faculty members and nominating new, high merit members are the basis of an effective university administration and suggested that this creates potential to receive higher quality of educational and consequent success for students post-graduation. If the faculty members are leaders in their respective fields, they should withhold the necessary leadership skills that qualify them to do their duty in building values, knowledge, and cadets' skills for long-term success and efficiency.

AIU plays a crucial role in many fields such as security and building future leaders. This unique characteristic of AIU requires the structured availability of leadership skills of faculty members, as the absence or weakness of 
leadership skills will eventually lead to graduate officers who lack the necessary leadership skills. Correspondingly, this study came to discover the availability of leadership skills of faculty members at AIU, civilian and military, in accordance with cadets' point of views.

\section{Problem and Questions of the Study}

AIU is an emerging university in Palestine that is seeking to establish a prestigious rank among the Arab universities, as it is the only university in Palestine that graduates police, military personnel, and security officers. Due to such excellence and the fact that the no study has been conducted to determine the leadership skills of both civilian and military instructors at AIU, the goal of the current study can be guided by the following two questions:

The first question is, "To what extent are the leadership skills available among faculty members at AIU as perceived by cadets?"

The second question is, "Do cadets' perceptions of the leadership skills available among faculty members differ by sex, academic level, and college?"

\section{Hypotheses of the Study}

This study tested the following null hypotheses:

1. There are no significant differences at $(\alpha \leq 0.05)$ in the cadets' perceptions of the leadership skills available among faculty members in AIU due to sex variable.

2. There are no significant differences at $(\alpha \leq 0.05)$ in the cadets' perceptions of the leadership skills available among faculty members in AIU due to the academic level variable.

3. There are no significant differences at $(\alpha \leq 0.05)$ in the cadets' perceptions of the leadership skills available among faculty members in AIU due to college variable.

\section{Definition of the Terms}

The current study contained the following operational definitions:

Skill

It is defined as the ability to accurately accomplish the work or task effectively, i.e., with a minimum of effort, cost and time.

\section{Al- Istiqlal University}

Al- Istiqlal University (AIU) is a newly established university that is considered to be the only one of its kind in Palestine. The ultimate scope of the university is to establish fully equipped officers to work efficiently with regards to keeping peace, maintaining domestic security, and serving the community.

Faculty members (military)

This term refers to those who teach at AIU (lecturers) and hold a Master qualification or higher, in addition to military rank.

Faculty members (civilians)

This term refers to those who teach at AIU (lecturers) and hold a Master degree or Ph. D. They do not hold any military rank.

\section{Theoretical Background}

Several terms accompanying the leadership concept have been developed since leadership underwent various stages during transformation. There were also several established theories to consider, such as Traits theory, Michigan Leadership Studies, Ohio State Leadership Studies, Managerial Grid, and X and Y theories. Moreover, these theories were followed by Contingency theories of Fiddler, Heresy and Blanchard. Furthermore, during the second half of the twentieth century, many terms were given for leadership. Examples of these terms include Transformational Leadership and Transactional Leadership (Abu Samra and Labadi, 2012). 
According to Rosemary and Richard (2012, p. 213), "Leadership is mostly about behavior. It is influence, nothing less than that." Al-Taweel (1986, p. 247) defined the concept of Leadership as, "A set of comprehensive harmonized concepts and cognitive, humanitarian and technical skills that the leader should have." He regarded leadership as collective concepts and skills that rely upon the ability to apply skills that one acquires from experience, study, and notice. Al- Khadra (2009) observed that a successful leader is one who not only withholds the appropriate skills, but also applies them effectively.

Generally speaking, Army Leadership withholds the same properties and traits of educational leadership. Sewell (2009, p. 93) defined Army Leadership according to the Army's leadership doctrinal manual Field Manual (FM 6-22) as, "the process of influencing people by providing purpose, direction, and motivation while operating to accomplish the mission and improve the organization." Krulak (1998) asserted that leaders in the field of education and leaders of Marines have substantial common ground, whether it be preparing young men and women for the defense of their nation or contributing to their moral, intellectual, and professional development as whole.

Faculty members collectively act as the base of a university and they play a crucial role in building up students' personalities and enriching them scientifically, intellectually, and socially and in terms of morale. They should have an accurate specialization, ability to debate, ability to control situations, fluency, analysis, inferring making comparison and connectivity. He should also be both a lecturer and artist who compiles the scientific material, invention, imagination, enthusiasm to work, motivation to express, professionalism in using teaching tools such as organized plausible style, clear and brief expression using proper language, effective distribution of questions, and clear and brief discourse on all subjects (Matiru et al, 2000). Feldman (1988) discussed the effect of faculty and members member skills on students, with a focus on the link between efficient education and intriguing lecturer's style and his speech skills. In the military domain, the importance of faculty and members member skills at military colleges is very apparent. Krulak $(1998$, p2) attempted to illustrate the vast responsibility that lies upon faculty members:

"We who work with young people have a great responsibility. It is not enough for us to harness their energy and guide them in their endeavors. We must also provide capable leadership and demonstrate strength of character in our daily lives. We are the examples on which they will pattern their lives. Opportunity lies at our feet. We have the chance not only to teach but also to influence the character of our young people - and hence the future of our society. We have the chance...to lead! “

Salley (2008), as mentioned in (Özlen and Zukic, 2013), attempted to determine the leadership styles which are suitable for each branch of the U. S. Army. He stated that the U. S. Military Academy (USMA) could make suitable branch recommendations to each cadet. He suggested that each graduating cadet indicate his or her preferred leadership style in order to increase overall military career contentment. Consequently, fewer USMA graduates retire from the military before satisfying their career in the army.

For the purposes to achieve objectives of institution, skills of leaders are considered crucial terms. In other words the leader should have skills that make him a leader; otherwise, he will be unqualified to be held to the standards of a true leader. He is to be most influential, satisfactory, capable of bearing responsibility, able to work as a team, transparent, and able to understand and effectively communicate with others (Baltas, 2001).

Due to the fact that influence withholds a crucial role in collective Army Leadership, it is critical to ensure influence capabilities, as they are integral elements of leader assessment and the development process. Thus, it is important to develop an understanding of the knowledge, skills, abilities, and other characteristics related to successful influence (Wisecarver et al, 2011).

It has been emphasized that leadership skills, which are necessary for university faculty members, either civilian or military, can be classified as the following (Bhatnagar and Aggarwal, 2009; Hersey and Blanchard, 1977):

\subsection{Firstly: Conceptual Skills}

It means the ability to understand the organization holistically. In addition, it indicates the ability to foster creative solutions to the problems that may arise in the workplace. The importance of conceptual skills appears in terms of the availability of faculty member at the extent of impact on the behavior of the students, as well as the impression that their actions leave by means of creativity, analysis, illation, comparison, and linkage.

\subsection{Secondly: Technical Skills}

It means the ability to use knowledge, methods, techniques, and the tools necessary for the performance of specific 
tasks. These skills relate to cognitive and specialist side of the faculty members, whether it is in regards to scientific specialization or educational in respect of his performance as a lecturer at a university. This can be demonstrated in dealing with modern teaching strategies skills, where these skills can normally be acquired through experience, training, and teaching.

\subsection{Thirdly: Human Skills}

It means the ability and judgment in working with and through people, including an understanding of motivation and an application of effective leadership. Human skills refer to skills of humanitarian relationships between faculty members with regards to their students and colleagues, and how to effectively employ concepts of human relations during class interaction. Such skills reflect on the ability of faculty members to deal with individuals. This requires mutual understanding between parties as well as the members and faculty member's knowledge of students' trends, consideration of student differences and various aptitudes, and the ability to work as a team, which ultimately requires straightness, honesty, faithfulness in work, and mutual trust. According to Kna'an (2009) the acquisition of human skills is more difficult and complex than the acquisition of technical skills because dealing with individuals is more complicated than dealing with objects.

\subsection{Fourthly: Individualistic Skills}

It represents certain traits possessed by the leader related to his personality including, but not limited to, physical abilities, brainpower, strong personality, fluency, flexible, risk-taker, ethical, humbleness, and fairness (Rosemary and Richard, 2012).

Consequently, such characteristics are deemed necessary for university lecturer to implement his role in building students' personalities and support society with scientific trained and aware qualifications to have an intact entity of community.

Many previous studies affirmed the importance of leadership skills for all organizations regardless of their specialization and outcomes. Oluwatoyin Bolanle (2013) sought to find out the leadership skills possessed by principals of public secondary schools in Southwestern Nigeria and the relationship between these leadership skills and school effectiveness in terms of student academic achievement. The descriptive survey research design was employed for the study. Findings revealed that secondary school principals in Southwestern Nigeria possessed technical, interpersonal, conceptual and administrative skills. A significant relationship was found between principals' leadership skills and overall school effectiveness.

Rosemary and Richard (2012) carried out a case study which was conducted at Masvingo Zimbabwe Open University to investigate worker's /lecturer's opinions about the skills that make an effective leader in an Open and Distance (ODL) learning institution. One general opinion expressed by participants was that good leadership requires deep human qualities such as fairness. Good leaders in ODL are an enabling force helping institutions and people to perform and develop. Ibrahim, Siraj and Mujir (2012) attempted to investigate whether the perceived leadership effectiveness of department heads in Malaysian polytechnics mediates the relationship between their leadership orientation and work commitment of lecturers. The study showed that the heads of department practiced multidimensional leadership, and the effect of this on lecturers' work commitment was, in-fact, mediated by lecturers' perception of department heads' leadership effectiveness.

According to Wisecarver et al (2011), Army leaders at all levels must be able to influence others across different types of missions, and because influence has a central role in leadership, thus it is necessary to have a comprehensive picture of the knowledge, skills, abilities, and other characteristics (KSAOs) underlying effective influence behaviors. To obtain this goal they reviewed existing academic and military literature regarding leader influence, knowledge, skills, abilities, and other characteristics (KSAOs) underlying effective influence behaviors, and training strategies that could be applied to develop these KSAOs. They identified leader influence strategies, described 64 KSAOs relevant to leader influence, and provided recommendations for measuring and training KSAOs. The identified KSAOs serve as targets for building training and assessment interventions designed to enhance army leader ability to influence. Moore and Rudd (2004) carried out a study sought to identify the major leadership skill areas and specific leadership competencies within each skill area needed by Extension leaders. Participants identified six major leadership skill areas needed by extension leaders: human, conceptual, technical, communication, emotional intelligence, and industry knowledge skills. A total of 80 specific leadership competencies were developed and clustered under one of the above six leadership skill areas. 


\section{Methodology}

The researcher employed the descriptive survey method; this method is suitable for these kinds of studies.

\subsection{Population and Sample of the Study}

The population of this study consisted of (303) male and female cadets. A stratified random sample, consisted of (137) cadets, was drawn up from the population of the study.

\subsection{Instrument}

The researcher used a three-point Likert scale (high, moderate and low) questionnaire, containing 40 items (skills), distributed to 4 aspects: conceptual, technical, human, and individualistic skills. The researcher distributed the questionnaire to a jury who is specialized in leadership (military and civilian) to confirm the validity of the questionnaire. The content was reviewed and $80 \%$ of the jury confirmed that the questionnaire suits the purposes of the study. A number of linguistic modifications were undergone. Cronbach Alpha formula was implemented to establish the reliability of the questionnaire, where it gained a score of $(0.95)$.

The researcher considered the following scale to determine the degree of the availability of the leadership skills:

- High: when the mean, $(\mathrm{X})$, of the item or the aspect is $[\mathrm{X} \geq 2.4 ; \mathrm{X} \geq(80 \%)]$.

- Moderate: when the mean is $[1.8<\mathrm{X}<2.4 ; 60 \%<\mathrm{X}<80 \%]$.

- Low: when the mean is $[\mathrm{X} \leq 1.8 ; \mathrm{X} \leq 60 \%]$.

\section{Results and Conclusion}

7.1 The first question: "To what extent are the leadership skills available among faculty members at AIU as perceived by cadets?"

Means and percentages of the cadets' perceptions were calculated. Table 1, shows the results of these perceptions according to the aspects of the skills.

Table 1. Means, Percentages and Standard Deviations

\begin{tabular}{clcccc}
\hline \multirow{2}{*}{ No. } & \multicolumn{1}{c}{ Aspect } & \multicolumn{2}{c}{ Civilian members } & \multicolumn{2}{c}{ Military members } \\
\cline { 3 - 6 } & & Means & SD & Means & SD \\
\hline 1 & Conceptual skills & 2.01 & $\mathbf{0 . 4 6}$ & $\mathbf{1 . 9 4}$ & $\mathbf{0 . 4 4}$ \\
2 & Technical skills & 2.15 & $\mathbf{0 . 4 3}$ & $\mathbf{2 . 0 0}$ & $\mathbf{0 . 4 3}$ \\
3 & Human skills & 2.12 & $\mathbf{0 . 4 7}$ & $\mathbf{2 . 0 2}$ & $\mathbf{0 . 4 6}$ \\
4 & Individualistic skills & 2.28 & $\mathbf{0 . 3 9}$ & $\mathbf{2 . 2 5}$ & $\mathbf{0 . 4 4}$ \\
$*$ & Total & $\mathbf{2 . 1 4}=\mathbf{( 7 1 . 3 \% )}$ & $\mathbf{0 . 3 8}$ & $\mathbf{2 . 0 5}=\mathbf{( 6 8 . 3 \% )}$ & $\mathbf{0 . 4 0}$ \\
$* *$ & Means total score & $\mathbf{2 . 1 0}=\mathbf{( 7 0 . 0 \% )}$ & & & $\mathbf{0 . 3 9}$ \\
\hline
\end{tabular}

It is obvious, as perceived by cadets, that the level of the leadership skills among faculty members at AIU, civilian and military, is moderate, according to the scale mentioned above, with average of (2.10), and forms a (70.0\%) percentage. Concerning the civilian members leadership skills overall means and percentages, they had (2.14) and $(71.3 \%)$, whereas it was (2.05) and (68.3\%) for military members. It can be inferred from the results above that AIU civilian members leadership skills level was higher than of those military members. Also, it appears from the results above that "individualistic skills" had the highest rank.

Referring to the means of the items, Appendix (1), we notice that:

- Only (2) items, related to the leadership skills of civilian lecturers, and (5) items related to the leadership skills of military lecturers, ranked less than $60 \%$.

- Concerning the military lecturers, (17) leadership skills got a mean of less than 2, on the other hand, (7) leadership skills of the civilian lecturers got less than 2 .

- Military and civilian lecturers were equally to the item that states, "Instructors try to increase cadets' morale." with an average of (2.07).

- Very few leadership skills were ranked as high and they were in favor of the civilian lecturers. 
- Such results are attributed to the fact that AIU is an emerging university. In addition, most of the military members are working at the Palestinian security agencies and do not have the potentials of qualified teachers. Moreover, the military cadres were used to the professional development in the field of security and military rather than in the field of teaching. Another reason that may be attributed to this result is the absence of academic higher educational institutions in Palestine which graduate qualified instructors in both teaching methodologies and security or military sciences. Furthermore, it might be attributed to the fact that all of the military instructors at AIU are members officers, in other words, they are not well-prepared to teach at universities.

7.2 The second question: "Do cadets' perceptions of the leadership skills available among faculty members differ by sex, academic level and college?"

To answer this question, the following hypotheses were tested:

7.2.1 The first hypothesis: There are no significant differences at $(\alpha \leq 0.05)$ in the cadets' perceptions of the leadership skills available among faculty members in AIU due to sex variable.

To test such hypothesis t-test was used. Table 2, shows the results.

Table 2. t-test for Differences Due to Sex Variable

\begin{tabular}{llllcl}
\hline Aspect & Variable & Mean & SD & t-value & Sign \\
\hline Conceptual Skills & Male & 1.99 & 0.376 & 0.610 & .543 \\
& Female & 1.95 & 0.403 & & \\
Technical Skills & Male & 2.09 & 0.386 & 0.760 & .449 \\
& Female & 2.04 & 0.342 & & \\
Human Skills & Male & 2.09 & 0.416 & 0.832 & .407 \\
& Female & 2.03 & 0.343 & & \\
Individualistic & Male & 2.26 & 0.329 & 0.019 & .985 \\
Skills & Female & 2.27 & 0.348 & & \\
Total & Male & 2.11 & 0.337 & 0.638 & .525 \\
& Female & 2.07 & 0.310 & & \\
\hline
\end{tabular}

The results of Table 2 demonstrate that there are no significant differences at $(\alpha \leq 0.05)$ between AIU cadets' perceptions of the availability of leadership skills of faculty members (civilian and military) due to any sex variable. This result may be attributed to the fact that both male and female cadets attend the same lectures and live in the same campus. Consequently, both males and females experience the same circumstances.

7.2.2 The second hypothesis: There are no significant differences at $(\alpha \leq 0.05)$ in the cadets' perceptions of the leadership skills available among faculty members in AIU due to academic level variable.

To test such hypothesis t-test was used. Table 3 illustrates the results.

Table 3. t-test for Differences Due to Academic Level Variable

\begin{tabular}{llrrrc}
\hline \multicolumn{1}{c}{ Aspect } & Variable & Mean & \multicolumn{1}{l}{ SD } & t-value & Sign \\
\hline Conceptual Skills & Sophomore & 1.93 & 0.408 & -1.27 & .203 \\
& Junior & 2.02 & 0.360 & & \\
Technical Skills & Sophomore & 2.06 & 0.380 & -.425 & .671 \\
& Junior & 2.09 & 0.364 & & \\
Human Skills & Sophomore & 2.03 & 0.410 & -1.09 & .277 \\
& Junior & 2.11 & 0.374 & & \\
Individualistic & Sophomore & 2.25 & 0.339 & -.534 & .594 \\
Skills & Junior & 2.28 & 0.334 & & \\
Total & Sophomore & 2.07 & .0 .338 & -.959 & .339 \\
& Junior & 2.12 & 0.318 & & \\
\hline
\end{tabular}


The results of Table 3 indicate that there are no significant differences at $(\alpha \leq 0.05)$ between AIU cadets' perceptions of the availability of leadership skills of faculty members due to the academic level variable. This result may be attributed to the teaching-learning environment. In other words, sophomores and juniors share some lectures especially compulsory courses. Moreover, cadets live on the university campus and meet in their leisure time. This leads to exchanging ideas, evaluations, and experiences with their lecturers' performance. Such environment may form a kind of consonance amongst them.

7.2.3 The third hypothesis: There are no significant differences at $(\alpha \leq 0.05)$ in the cadets' perceptions of the leadership skills available among faculty members in AIU due to college variable.

To test this hypothesis, One-Way ANOVA was implemented. The results are clear in table 4.

Table 4. Results of One-way ANOVA Due to College Variable

\begin{tabular}{lccccccc}
\hline No. & Aspect & Source of Variance & $\begin{array}{c}\text { Sum of } \\
\text { Squares }\end{array}$ & D F & $\begin{array}{c}\text { Mean } \\
\text { Square }\end{array}$ & F & Sign \\
\hline 1. & Conceptual & Between groups & 0.321 & 2 & .161 & 1.08 & .341 \\
& Skills & within groups & 19.8 & 134 & .148 & & \\
& & Total & 20 & 136 & & & \\
2. & Technical Skills & Between groups & 0.256 & 2 & .128 & .931 & .397 \\
& & within groups & 18.4 & 134 & .137 & & \\
& & Total & 18.65 & 136 & & & \\
3. & Human Skills & Between groups & 0.182 & 2 & .091 & .588 & .557 \\
& & within groups & 20.7 & 134 & .155 & & \\
& & Total & 20.9 & 136 & & & \\
4. & Individualistic & Between groups & 0.78 & 2 & .039 & .344 & .710 \\
& Skills & within groups & 15.1 & 134 & .113 & & \\
& & Total & 15.2 & 136 & & & \\
& Total & Between groups & .072 & 2 & .036 & .331 & .719 \\
& & Within groups & 14.5 & 134 & .108 & & \\
& & Total & 14.5 & 136 & & & \\
\hline
\end{tabular}

Table (4) shows that there are no significant differences present at $(\alpha \leq 0.05)$ between AIU cadets' perceptions of the availability of leadership skills of faculty members due to the college variable. This result sums up the previous ones as cadets live under the same circumstances, share ideas in their leisure time, being taught by the same lecturers for a majority of their time. Consequently, they will have a common philosophy and thought about the leadership skills of their lecturers.

\section{Recommendations}

Based on the results of the study, the researcher recommends that AIU should contribute a great deal of attention towards the conducive planning and implementation of resources to teach faculty members leadership skills through training courses or forums in their respective fields. Also, AIU should aim to hire experienced teaching members who have sufficient teaching skills, adequate leadership traits, and enthusiasm to learn and implement the recommended resources for student, college, staff, and collective university advancement.

\section{Acknowledgment}

The author would like to thank Mrs. Hadil Katato- Abu Samra for her copyediting of the manuscript. 


\section{References}

Abu Samra, M. A., \& Labadi, R. (2012). Degree of practicing of principal in Jerusalem schools to his/her role as an instructional leader. JAMI 'A, 16, 201- 238.

Al -Khadra, B., Ahmed, M., Abu Hantash, A., \& Al Taher, J. (2009). Organizational Behavior. Amman: Al Quds Open University.

Al -Taweel, H. (1986). Administration and Organizational Behavior. Amman: Jordan University.

Baltas, A. (2001). Teamwork and Leadership. Istanbul: Remzi Bookshop.

Bhatnagar, R. P., \& Aggarwal, V. (2009). Educational Administration: Supervision, Planning, and Financing. Vinary Rakheja, Meerut.

Hersey, P., \& Blanchard, K. (1977). Management of Organizational Behavior( $3^{\text {rd }}$ ed.). Prentice-Hall, NY.

Ibrahim, M. S., Siraj, S., \& Mujir, S. J. M. (2012). Multidimensional leadership Orientations and lecturers' work commitment: the mediation of leadership effectiveness among Malaysian Polytechnic heads of department. Asian Journal of Teaching and Learning in Higher Education, 4(2), 33-50.

Kna'an, N. (2009). Administrational Leadership. Amman: The Cultural Dar for Publishing and Distribution.

Krulak, C. (1998). The Fourteen Basic Traits of Effective Leadership. About Campus, 3(4), retrieved from EBSCO data base, April 1, 2014.

Matiru, B., Mwangi., \& Schelette. (2000). Teach Your Best: A Handbook for University Lecturers. Translated to Arabic by Hussein A and Majed M, Amman: Dar Al Shoroq.

McGonigle, D., Mastrian, K., Farcus, N., Egger, R, M., \& Shoop. L. (2002). Nurturing Faculty: An Old Concept. Journal of Academic Leadership,2(1). Retrieved 20 March, 2014 from: http://academic leadership.org/cgi bin/document.cgi? File=5/article3.dhtm

Moore, L.L., \& Rudd, R. (2004). Leadership skills and competences for extension directors and administrators. Journal of Agricultural Education, 45(3), 22-33. http://dx.doi.org/10.5032/jae.2004.03022

Oluwatoyin Bolanle, A. (2013). Principals' Leadership Skills and School Effectiveness: The Case of South Western Nigeria. World Journal of Education, 5(3), 26-33.

Özlen, M. K., \& Zukic, A. (2013). A Descriptive Study on the Military Leadership. International Journal of Academic Research in Business and Social Sciences, 3(7), 707-719. http://dx.doi.org/10.6007/IJARBSS/v3-i7/102

Rosemary, N., \& Richard, N. (2012). Leadership Skills in ODL: Perceptions of Lecturers at Masvingo Zimbabwe Open University. International Journal of Social Sciences and Education, 3(1), 211-220.

Sewell, G. F. (2009). Emotional Intelligence and the Army Leadership Requirements Model. Military Review, (NovDec, 2009), 93- 98.

Wisecarver, M., Schneider, R., Folder, H., Cullen, M., \& Zbylut, M. R. (2011). Knowledge, Skills, and Abilities for Military Leadership Influence. Technical Report 1281. U. S Army Research Institute for Behavioral and School Sciences, Arlington, Virginia. 
Appendix (1)

\begin{tabular}{|c|c|c|c|c|c|}
\hline \multirow{2}{*}{ No. } & \multirow[t]{2}{*}{ Conceptual Skills } & \multicolumn{2}{|c|}{ Civilian } & \multicolumn{2}{|c|}{ Military } \\
\hline & & Mean & $S D$ & Mean & $S D$ \\
\hline 1 & $\begin{array}{l}\text { Lecturers are featured of being innovated in raising their courses' } \\
\text { subjects. }\end{array}$ & 2.13 & .62 & 2.09 & .64 \\
\hline 2 & Lecturers stir up students' motivation to learn. & 1.98 & .70 & 1.85 & .70 \\
\hline 3 & $\begin{array}{l}\text { They prepare helpful educational activities that promote students' } \\
\text { thoughts }\end{array}$ & 1.92 & .74 & 1.72 & .73 \\
\hline 4 & $\begin{array}{l}\text { They make inventive solutions for troubles that students face in } \\
\text { university }\end{array}$ & 1.77 & .77 & 1.59 & .71 \\
\hline 5 & They enhance leadership sides of students & 1.99 & .73 & 2.27 & .71 \\
\hline 6 & They work on exploring students' inventive capabilities. & 1.89 & .75 & 1.69 & .64 \\
\hline 7 & They reinforce students' trust of themselves. & 2.04 & .70 & 2.03 & .75 \\
\hline 8 & $\begin{array}{l}\text { They encourage students to constructively think to deal with their } \\
\text { future problems }\end{array}$ & 2.13 & .76 & 1.82 & .73 \\
\hline 9 & They link between teaching at university and students future work. & 2.10 & .73 & 2.13 & .81 \\
\hline 10 & They clarify the privacy of AIU during teaching their courses. & 2.28 & .64 & 2.22 & .74 \\
\hline & Total score of the aspect & 2.01 & 0.46 & 1.94 & 0.44 \\
\hline \multicolumn{6}{|c|}{ Technical Skills } \\
\hline 11 & $\begin{array}{l}\text { Lecturers help their students understand general objectives of the } \\
\text { curriculum }\end{array}$ & 2.30 & .70 & 2.09 & .72 \\
\hline 12 & They keen on reaching the correct information to students & 2.45 & .65 & 2.36 & .70 \\
\hline 13 & $\begin{array}{l}\text { They have an adequate knowledge of the content of courses they } \\
\text { teach. }\end{array}$ & 2.37 & .62 & 2.16 & .70 \\
\hline 14 & They use various tools and methods in teaching & 2.04 & .74 & 1.95 & .72 \\
\hline 15 & They exercise interesting ways of teaching that attract students & 1.79 & .70 & 1.85 & .76 \\
\hline 16 & They utilize a range of evaluation methods & 1.92 & 69 & 1.77 & .63 \\
\hline 17 & $\begin{array}{l}\text { They make use of suitable educational tools that commensurate with } \\
\text { curriculum content }\end{array}$ & 2.04 & .72 & 1.88 & .73 \\
\hline 18 & Lecturers employ modern educational technologies in lecture & 2.21 & .67 & 1.91 & .73 \\
\hline 19 & They posses skills of the successful class conduct & 2.16 & .66 & 2.13 & .67 \\
\hline 20 & They frankly discuss with students the subjects of courses & 2.26 & .76 & 1.98 & .79 \\
\hline \multicolumn{2}{|c|}{ Total score of the aspect } & 2.15 & 0.43 & 2.00 & 0.43 \\
\hline
\end{tabular}




\begin{tabular}{|c|c|c|c|c|c|}
\hline \multicolumn{2}{|r|}{ Human Skills } & & & & \\
\hline 21 & They pay attention to listen to students' opinions and suggestions & 2.17 & .73 & 1.99 & .78 \\
\hline 22 & They work on developing humanitarian relations between students & 2.07 & .73 & 2.10 & .75 \\
\hline 23 & They improve positive trends and ethics of students & 2.27 & .70 & 2.15 & .68 \\
\hline 24 & They argue students for the purpose of convince and satisfaction & 2.18 & .72 & 1.90 & .78 \\
\hline 25 & They highly appreciate students' distinct achievements & 2.12 & .77 & 1.91 & .79 \\
\hline 26 & They are away from embarrassing students & 1.99 & .76 & 1.77 & .78 \\
\hline 27 & $\begin{array}{l}\text { They exert their efforts in solving student's problems according to } \\
\text { their powers }\end{array}$ & 2.03 & .79 & 1.96 & .78 \\
\hline 28 & They support their students to work as a team & 2.23 & .69 & 2.21 & .72 \\
\hline 29 & They represent themselves as a good example for their students & 2.15 & .69 & 2.16 & .688 \\
\hline 30 & They raise morale of students & 2.07 & .72 & 2.07 & .724 \\
\hline \multicolumn{2}{|r|}{ Total score of the aspect } & 2.12 & 0.47 & 2.02 & 0.46 \\
\hline \multicolumn{6}{|c|}{ Individualistic Skills } \\
\hline 31 & Ability to make the right decision in due time & 2.25 & .69 & 2.26 & .72 \\
\hline 32 & Self-trust & 2.36 & .61 & 2.47 & .595 \\
\hline 33 & Persuasion & 2.24 & .67 & 2.18 & .69 \\
\hline 34 & Enthusiasm and vitality at work & 2.16 & .67 & 2.26 & .74 \\
\hline 35 & Good appearance (Presentable) & 2.55 & .59 & 2.47 & .65 \\
\hline 36 & Accuracy of observation & 2.23 & .59 & 2.38 & .68 \\
\hline 37 & Communication and contact skill & 2.30 & .63 & 2.15 & .706 \\
\hline 38 & Calm and not being emotional & 2.12 & .66 & 1.89 & .78 \\
\hline 39 & Fluency & 2.39 & .64 & 2.26 & .71 \\
\hline 40 & Ability to analyze attitudes and situations & 2.20 & .68 & 2.28 & .68 \\
\hline & Total score of the aspect & 2.28 & 0.39 & 2.25 & 0.44 \\
\hline \multicolumn{2}{|r|}{ Total score of the questionnaire } & 2.14 & 0.38 & 2.05 & 0.40 \\
\hline
\end{tabular}

